\title{
TERHADAP KEPUTUSAN NASABAH DALAM MEMILIH JASA PERBANKAN PADA PT. BANK BRI CABANG MATARAM
}

\author{
Baiq Noviana Krisnawaty1 \\ Lalu Suparman2 \\ Akhmad Saufi ${ }^{3}$
}

\begin{abstract}
This study aims to determine the effect of the elements of corporate image that is personality, reputation, value, and corporate and analyze the variables that have a dominant influence on the customer's decision in choosing banking services at PT. Bank BRI Cabang Mataram. This research is expected to provide benefits such as: Academically, the requirement for unanimity courses Masters (S2) in the Management Program, University of Mataram. Theoretically, this study is one opportunity to apply the knowledge acquired during the Marketing Management in college. In practical terms, the expected results of the study can be used as consideration for PT. Bank BRI Cabang Mataram to promote the company. This type of research is associative causal research and sampling techniques using accidental sampling as many as 100 customers of Bank BRI Cabang Mataram. Analysis techniques used is Multiple Linear Regression.

The results showed that: personality significantly influence the customer's decision. Reputation significantly influence the customer's decision. Value significantly influence the customer's decision. corporate significantly influence the customer's decision. The dominant variables strongly influence the customer's decision that personality factors BRI Bank Cabang Mataram. Overall personality, reputation, value, and corporate significantly influence the customer's decision.

Then, the most important thing and should not be overlooked is that in a business, especially PT. Bank BRI Cabang Mataram is idealism product or performance that must be constantly maintained and improved. Because this is what distinguishes between other Cabang Bank BRI Unit and Other Bank.
\end{abstract}

Keywords: Decision of customers, Elements of corporate image.

\section{PENDAHULUAN}

Bank merupakan salah satu lembaga keuangan yang berfungsi utama dalam menghimpun dana dari masyarakat dan menyalurkannya kembali kepada masyarakat untuk berbagai tujuan atau sebagai financial intermediary (Sinungan, 2000:3). Jadi fungsi utama bank sebagai lembaga keuangan yang ada di Lombok adalah sebagai penghimpun dan penyalur dana kepada masyarakat yang ada di Wilayah Lombok. Jadi uang yang di himpun bank dari masyarakat di Wilayah Lombok akan digunakan untuk pembangunan yang dapat di nikmati oleh masyarakat. Maksudnya adalah dana-dana simpanan yang berhasil dihimpun akan disalurkan kepada pihak-pihak yang membutuhkan, contohnya melalui penyaluran kredit yang dapat meratakan pembangunan antara cabang Bank di kota - kota besar dengan cabang bank di desa desa yang ada di Wilayah Lombok.

\footnotetext{
${ }^{1}$ Mahasiswa Pasca Sarjana UNRAM Program Magister Manajemen

2 Dosen Pasca Sarjana UNRAM Program Magister Manajemen
} 
Perkembangan perbankan yang ada di wilayah Lombok tumbuh pesat dan mengalami persaingan ketat. Beberapa Bank yang ada di Lombok diantaranya antara lain Bank BNI 46, Bank Mandiri, Bank Bukopin, Bank Danamon, Bank NTB, Bank BRI, dan bank lainnya.

Melihat hal persaingan yang sangat tinggi di antara lembaga perbankan, maka masing-masing Bank berupaya untuk memberikan pelayanan terbaik atau pelayanan prima kepada nasabah. Sehingga Bank-bank tersebut memiliki citra yang baik di benak publik.

Menurut Dowling (dalam Nha Nguyen, 2001:63), citra perusahaan adalah : "Corporate image is the consumer's response to the total offering and is defined as a sum the belief, ideas, and impressions that a public has an organization."Artinya citra perusahaan adalah respon konsumen pada keseluruhan penawaran yang diberikan perusahaan dan didefinisikan sebagai sejumlah kepercayaan, ide-ide, dan kesan masyarakat pada suatu organisasi".

Berdasarkan penelitian yang dilakukan oleh Yusrina, (2013), tentang Peranan Citra Perusahaan Terhadap Kepercayaan Nasabah Bank BRI Cabang Banda Aceh. Hasil identifikasi dalam penelitian ini, dimana terdapat fenomena umum sehubungan dengan perilaku nasabah dalam memilih lembaga perbankan banyak di antara nasabah sebelumnya menjadi nasabah bank lain selain Bank BRI, justru kemudian menjadi Bank BRI Cabang Banda Aceh. Sebaliknya juga ada di antara nasabah yang dulunya menjadi nasabah Bank BRI Cabang Banda Aceh, juga menjadi nasabah bank lain. Perilaku seperti ini tentunya dapat dijadikan indikasi adanya perbedaan kepercayaan dikalangan nasabah terhadap bank tersebut. Kepercayaan terhadap bank tentunya tidak terlepas dari baik buruknya citra bank di benak konsumen.

Selanjutnya, penelitian yang dilakukan oleh Ulfa (2006), tentang hubungan antara citra merek dengan loyalitas nasabah PT. Bank Rakyat Indonesia (Persero) Tbk. Kantor Cabang Purbalingga. Hasil penelitian membuktikan bahwa ada hubungan positif yang signifikan antara citra merek dengan loyalitas nasabah. Arah hubungan positif antara citra merek dengan loyalitas nasabah artinya semakin tinggi atau positif citra merek suatu bank di mata nasabahnya maka akan semakin tinggi loyalitas nasabah, atau semakin rendah atau negatif citra merek maka semakin rendah pula loyalitas nasabah.

Khasali (2003:28) mengemukakan, "pemahaman yang berasal dari suatu informasi yang tidak lengkap menghasilkan citra yang tidak sempurna". Dia juga mengemukakan, informasi yang lengkap mengenai citra perusahaan meliputi empat elemen sebagai berikut: (1). Personality, keseluruhan karakteristik perusahaan yang dipahami publik sasaran seperti perusahaan yang dapat dipercaya, perusahaan mempunyai tanggung jawab sosial. (2). Reputation. Hal yang dilakukan perusahaan dan diyakini publik sasaran berdasarkan pengalaman sendiri maupun pihak lain, seperti kinerja keamanan transaksi sebuah bank, pelayanan yang memuaskan. (3). Value. Nilainilai yang dimiliki perusahaan dengan kata lain budaya perusahaan seperti sikap manajemen yang peduli terhadap pelanggan, karyawan yang cepat tanggap terhadap permintaan maupun keluhan pelanggan. (4). Corporat identity. Adalah Komponen-

\footnotetext{
${ }^{1}$ Mahasiswa Pasca Sarjana UNRAM Program Magister Manajemen

2 Dosen Pasca Sarjana UNRAM Program Magister Manajemen
} 
komponen yang mempermudah mengenal publik sasaran terhadap perusahaan seperti logo, warna dan slogan.

Bank Rakyat Indonesia (BRI) adalah salah satu bank milik pemerintah yang terbesar di Indonesia. Pada awalnya Bank Rakyat Indonesia (BRI) didirikan di Purwokerto, Jawa Tengah oleh Raden Bei Aria Wirjaatmadja dengan nama De Poerwokertosche Hulpen Spaarbank der Inlandsche Hoofden atau "Bank Bantuan dan Simpanan Milik Kaum Priyayi Purwokerto", suatu lembaga keuangan yang melayani orang-orang berkebangsaan Indonesia (pribumi). Lembaga tersebut berdiri tanggal 16 Desember 1895, yang kemudian dijadikan sebagai hari kelahiran BRI (sumber: http://www.bri.co.id/articles/9).

Tabel 1. Jumlah Cabang Bank BRI di Wilayah Kerja Kantor Cabang Mataram.

\begin{tabular}{|c|l|l|}
\hline No & CABANG BRI & \multicolumn{1}{|c|}{ Alamat } \\
\hline 1 & Kantor Cabang Mataram & Jl. Pejanggik No. 16, Mataram \\
\hline 2 & $\begin{array}{l}\text { Kantor Cabang Pembantu } \\
\text { Cakranegara }\end{array}$ & $\begin{array}{l}\text { Jl. Pejanggik No. 36B, Kec. Cakranegara, } \\
\text { Mataram }\end{array}$ \\
\hline 3 & $\begin{array}{l}\text { Kantor Cabang Pembantu } \\
\text { Sriwijaya }\end{array}$ & $\begin{array}{l}\text { Jl. Sriwijaya, Komp. Pertokoan No. 2, } \\
\text { Mataram }\end{array}$ \\
\hline 4 & Unit Ampenan & Jl. Yos Sudarso \\
\hline 5 & Unit Kebon Roek & $\begin{array}{l}\text { Jl. Adi Sucipto, Kmplk Pertokoan Kebon } \\
\text { Roek. }\end{array}$ \\
\hline 6 & Unit Cakranegara & Jl. Selaparang No. 25 \\
\hline 7 & Unit Airlangga & Jl. Airlangga No. 25F \\
\hline 8 & Unit Bung Karno & Jl. Bung Karno Pagutan, Teras Pasar \\
\hline 9 & Unit Pemenang & Jl. Raya Pemenang \\
\hline 10 & Unit Tanjung & Jl. Tanjung Raya \\
\hline 11 & Unit Sayang-Sayang & $\begin{array}{l}\text { Jl. Ahmad Yani Komplek Pasar Sayang- } \\
\text { sayang }\end{array}$ \\
\hline 12 & Unit Pagesangan & Jl. K.H.Ahmad Dahlan, Pagesangan \\
\hline 13 & Unit Gerung & Jl. Ahmad Yani Gerung \\
\hline 14 & Unit Narmada & Jl. Raya Narmada \\
\hline 15 & Unit Gunungsari & Jl. Raya Gunung Sari, Tanjung No. 3 \\
\hline 16 & Unit Bagik Polak & Jl. Teguh Lopan \\
\hline 17 & Unit Sweta & Jl. Raya Sanndubaya Blok C No. 5 \\
\hline 18 & Unit Kediri & Jl. Raya Tgh Ibrahim Holidi Kediri \\
\hline 19 & Teras Pasar Mandalika & Mandalika, Kec. Sandubaya Mataram \\
\hline 20 & Teras Pasar Abian Tubuh & Jl. Aa Gede Ngurah Cakranegara \\
\hline & Sumber : BRI Cabang Mataram & \\
\hline
\end{tabular}

Bank BRI memiliki 20 unit cabang yang tersebar di kota mataram dan Bank BRI semakin memberikan prospek yang baik karena kebutuhan masyarakat akan perbankan terus meningkat seiring dengan pertumbuhan jumlah penduduk.

\footnotetext{
${ }^{1}$ Mahasiswa Pasca Sarjana UNRAM Program Magister Manajemen

2 Dosen Pasca Sarjana UNRAM Program Magister Manajemen
} 
Masyarakat kota maupun desa kini mulai banyak menggunakan jasa Bank BRI karena bank BRI mempermudah setiap nasabah baik yang membutuhkan dana maupun kredit.

Bank BRI Cabang Mataram sebagai salah satu lembaga keuangan di Kota Mataram telah memberikan pelayanan kepada masyarakat sesuai dengan fungsi sebagai lembaga keuangan, bank tersebut tidak hanya menerima simpanan dana masyarakat yang dalam hal ini adalah nasabah simpanan, akan tetapi juga menyalurkan dana tersebut kepada masyarakat yang membutuhkan dana.

Tabel 2. Jenis Produk PT. Bank BRI

\begin{tabular}{|l|l|l|l|}
\hline \multirow{2}{*}{ No. } & \multicolumn{3}{|c|}{ Jenis Produk } \\
\cline { 2 - 4 } & Simpanan & \multicolumn{1}{|c|}{ Kredit } \\
\cline { 2 - 4 } & Jangka Pendek & Jangka Panjang & \multicolumn{1}{|c|}{ Jangka Pendek } \\
\hline 1 & Simpedes & DPLK & Suku bunga menurun \\
2 & $\begin{array}{l}\text { Britama : Junio }(>17 \text { th \& }<17 \text { th), } \\
\text { Clasic, Gold, Bisnis, Mean Of Steel }\end{array}$ & & Suku bunga tetap \\
\hline
\end{tabular}

Sumber: PT Bank BRI Cabang Mataram

Berdasarkan tabel diatas, jenis produk PT. Bank BRI yaitu terdiri dari dua katagori yaitu nasabah simpanan dan nasabah kredit dengan simpanan jangka pendek terdiri dari Simpedes dan Britama. Sedangkan dalam jangka panjang terdiri dari DPLK dan Britama Rencana.

Berdasarkan survei dilakukan di Kota Mataram, terdapat beberapa bank besar yang menjadi pilihan bagi masyarakat dalam menggunakan jasa Bank, seperti Bank BNI 46, Bank Mandiri, Bank Bukopin, Bank Danamon, Bank NTB, Bank BRI, dan bank lainnya. Beberapa Bank tersebut terlihat mudah dijangkau oleh masyarakat seperti lokasinya yang strategis dan produk yang ditawarkan, serta adanya kualitas Bank yang bermutu tinggi. Salah satu riset yang dilakukan oleh Lembaga Riset MARS yang meneliti kepada masyarakat tentang pemikiran pertama kali ketika mereka menyebutkan nama bank. Hasil yang diperoleh empat dari sepuluh orang Indonesia mengatakan bank BCA ketika ditanya tentang bank, disusul BNI, BRI, Bali, Lippo, Danamon, BII, dan BTN (Sumber: Bank Brand Performance,1999 di kutip di https://idtesis.com/tingkat-kepuasan-nasabah-bri-analisis-tingkat-kepentingan/).

Bank Rakyat Indonesia Cabang Mataram berusaha memberikan pelayanan dan fasilitas yang sesuai dengan harapan nasabah tujuannya untuk mempertahankan nasabah yang sudah ada serta mendapatkan calon nasabah dan berusaha menjadi bank yang terbaik dan terdepan dalam memuaskan nasabah-nasabahnya, sesuai dengan slogan Bank BRI yaitu melayani dengan sepenuh hati. Disisi lain, Bank BRI memiliki keunggulan tersendiri dibandingkan bank lain, seperti adanya citra bank BRI di mata masyarakat sangat baik, terbukti dengan banyaknya jumlah nasabah yang menabung di bank BRI Cabang Mataram.

Berdasarkan wawancara yang dilakukan oleh peneliti dengan beberapa manajer pada Bank BRI, pihak perusahan sudah memaksimalkan melakukan perbaikan kinerja di masing-masing cabang perusahaan dan dibuktikan dalam beberapa tahun ini, bank BRI semakin dipercayai oleh nasabah dalam hal menabung uang di Bank, dimana perusahaan (Bank BRI) menunjukkan inovasi produk yang terus dilakukan saat ini

\footnotetext{
${ }^{1}$ Mahasiswa Pasca Sarjana UNRAM Program Magister Manajemen

2 Dosen Pasca Sarjana UNRAM Program Magister Manajemen
} 
jumlah penabungnya bertambah setiap tahunnya dan Bank BRI melakukan perbaikan dengan meningkatkan citra perusahaan bank BRI di mata nasabahnya. Melalui usaha tersebut, ternyata memang masih banyak nasabah yang tetap bertahan dan loyal terhadap bank BRI, meskipun terjadi sedikit penurunan jumlah nasabah.

\section{TUJUAN PENELITIAN}

a). Untuk menganalisis dan mengetahui signifikansi pengaruh dari personality sebagai elemen citra perusahaan terhadap Keputusan Nasabah dalam memilih Jasa Perbankan.

b). Untuk menganalisis dan mengetahui signifikansi pengaruh dari reputation sebagai elemen citra perusahaan terhadap Keputusan Nasabah dalam memilih Jasa Perbankan.

c). Untuk menganalisis dan mengetahui signifikansi pengaruh dari value sebagai elemen citra perusahaan terhadap Keputusan Nasabah dalam memilih Jasa Perbankan.

d). Untuk menganalisis dan mengetahui signifikansi pengaruh dari corporate sebagai elemen citra perusahaan terhadap Keputusan Nasabah dalam memilih Jasa Perbankan.

e). Untuk mengetahui di antara variabel personality, reputation, value, dan corporate yang memiliki pengaruh paling dominan terhadap Keputusan Nasabah dalam memilih Jasa Perbankan.

\section{LANDASAN TEORI}

\subsection{Perilaku Konsumen}

Kotler dan Keller (2008:214): Perilaku konsumen adalah studi bagaimana individu, kelompok dan organisasi memilih, membeli, menggunakan dan menempatkan barang, jasa, ide atau pengalaman untuk memuaskan keinginan dan kebutuhan mereka.

Perilaku konsumen adalah perilaku yang ditunjukan oleh konsumen dalam mencari, membeli, menggunakan, mengevaluasi dan menghentikan konsumsi produk, jasa, dan gagasan (Schiffman, 2008).

Kanuk (2008:45) mengatakan bahwa perilaku konsumen adalah proses pencarian informasi mengenai suatu produk atau jasa pada saat pembelian, menggunakan, dan mengkonsumsi serta mengevaluasi produk yang dapat memberikan kepuasan kepada pelanggan.

Dari pengertian tentang perilaku konsumen di atas dapat diperoleh beberapa hal yang penting, yaitu: (1) sebagai kegiatan fisik dan (2) sebagai proses pengambilan keputusan. Berdasarkan beberapa definisi yang telah disebutkan di atas dapat disimpulkan bahwa perilaku konsumen adalah semua kegiatan, tindakan, serta proses psikologis yang mendorong tindakan tersebut pada saat sebelum menggunakan jasa, ketika menggunakan jasa, menggunakan, menghabiskan produk dan jasa setelah melakukan hal-hal di atas atau kegiatan mengevaluasi.

\footnotetext{
${ }_{1}$ Mahasiswa Pasca Sarjana UNRAM Program Magister Manajemen

2 Dosen Pasca Sarjana UNRAM Program Magister Manajemen
} 


\section{JURNAL MAGISTER MANAJEMEN \\ UNIVERSITAS MATARAM \\ September 2016}

\subsection{Keputusan Nasabah}

Menurut Salusu (2003), pengambilan keputusan adalah proses memilih alternatif-alternatif bagaimana cara bertindak dengan metode efisien sesuai dengan situasi. Definisi tersebut sejalan dengan Terry (dalam Ibnu Syamsi, 1995) yang menyatakan bahwa pengambilan keputusan adalah pemilihan alternatif perilaku dari dua alternatif atau lebih, tindakan untuk memecahkan masalah yang dihadapi melalui pemilihan satu diantara alternatif-alternatif yang memungkinkan.

Menurut Salusu (2003:47) mengemukakan bahwa: "Keputusan nasabah ialah proses memilih suatu alternatif cara bertindak dengan metode yang efisien sesuai situasi."

Dari pendapat para ahli diatas dapat disimpulkan bahwa keputusan nasabah adalah proses memilih berbagai alternatif yang ada pada perusahaan dan sesuai dengan kepentinagnnya dalam menentukan pilihan yang sesuai dengan situasi.

\subsection{Tahap - Tahap Konsumen Dalam Melakukan Keputusan Pembelian}

Tahap-tahap konsumen dalam melakukan keputusan pembelian (Kotler, 2005:224) yaitu :

1. Pengenalan Masalah

Konsumen memulai proses pembelian ketika menyadari suatu masalah atau kebutuhan yang belum didapatnya, dengan melakukan pembelian konsumen mengharapkan masalah atau kebutuhan tersebut dapat teratasi. Beragam dan banyaknya perbedaan antara masalah atau kebutuhan setiap konsumen menuntut pemasar agar dapat melakukan penilaian dan identifikasi pada saat tertentu dengan mengumpulkan informasi dari sejumlah konsumen sehingga dapat mengetahui apa dan bagaimana masalah atau kebutuhan konsumen, dan kapan konsumen membutuhkan solusi atas permasalahan dan kebutuhannya.

2. Pencarian Informasi

Tahap pertama ketika konsumen mengetahui dan menyadari masalah atau kebutuhannya maka konsumen akan melakukan pencarian informasi mengenai solusi atas permasalahan atau kebutuhan tersebut. Melakukan pencarian informasi dilakukan konsumen untuk mengetahui dengan lebih jelas solusi terbaik atas masalah atau kebutuhannya tersebut.

Sumber utama konsumen ketika melakukan pencarian informasi dibagi menjadi empat kelompok, yaitu :

a). Pribadi : Keluarga, teman, tetangga, dan rekan.

b). Komersial : Iklan, situs web, wiraniaga, penyalur, dan kemasan

c). Publik : Media massa, organisasi pemeringkat konsumen

d). Experimental : Penanganan, pemeriksaan, penggunaan produk.

Masing-masing sumber informasi mempunyai fungsi dan tingkat kepercayaan konsumen yang berbeda-beda, sumber informasi yang paling efektif sering berasal dari sumber pribadi atau sumber publik yang merupakan otoritas independen (Kotler\&Keller, 2008). Sumber informasi pribadi menarik kesimpulan sebuah informasi tentang produk atau jasa dari pengalaman selama memakai produk atau jasa.

\footnotetext{
${ }^{1}$ Mahasiswa Pasca Sarjana UNRAM Program Magister Manajemen

2 Dosen Pasca Sarjana UNRAM Program Magister Manajemen
} 


\section{JURNAL MAGISTER MANAJEMEN \\ UNIVERSITAS MATARAM \\ September 2016}

3. Evaluasi Alternatif

Setelah selesai dengan melakukan pencarian informasi konsumen

memiliki berbagai pilihan dan alternatif sebagai solusi dari masalah atau kebutuhannya. Berbagai sumber informasi dan referensi dijadikan bahan penilaian konsumen untuk mengambil keputusan dari alternatif-alternatif yang ada.

Kotler (2008) merumuskan beberapa konsep dasar yang membantu untuk memahami proses evaluasi :

a). Konsumen berusaha memuaskan sebuah kebutuhan.

b). Konsumen mencari manfaat tertentu dari solusi produk.

c). Konsumen melihat masing-masing produk sebagai sekelompok atribut dengan berbagai kemampuan untuk menghantarkan manfaat yang diperlukan untuk memuaskan kebutuhan ini.

4. Keputusan Pembelian

Setelah tahap evaluasi alternatif, konsumen dapat menentukan pilihan berdasarkan alternatif yang ditawarkan dan konsumen sudah memiliki keputusan tentang alternatif yang dipilihnya. Keputusan pembelian untuk solusi dari masalah atau kebutuhannya mengharuskan konsumen siap atas risiko dari keputusannya.

5. Perilaku Pascapembelian

Setelah melaksanakan setiap tahap-tahap yang telah diuraikan sebelumnya, maka konsumen dapat merasakan secara langsung apakah telah mendapat solusi dari masalah atau kebutuhannya telah sesuai dengan yang diinginkan atau tidak sesuai dengan keinginan dan belum mendapatkan solusi atas permasalahan atau kebutuhannya karena tidak puas dengan solusi yang ditawarkan.

Gambar 1. Proses Keputusan Pembelian

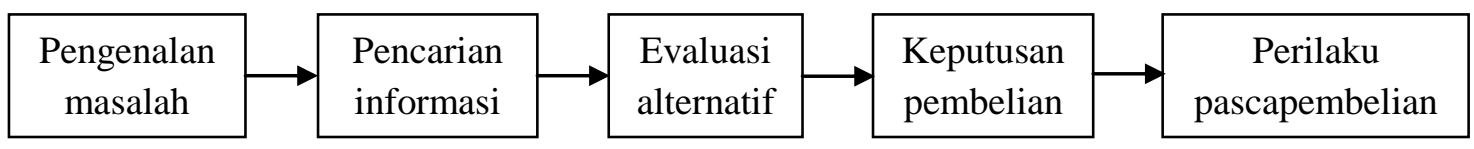

Sumber : Kotler, (2005:224)

\subsection{Citra Perusahaan}

Menurut Sutisna (2001:83), menyatakan bahwa citra sebagai total persepsi terhadap suatu objek yang dibentuk dengan memproses informasi dari berbagai sumber setiap waktu. Sedangkan Alma (2002:317) mendefenisikan citra sebagai kesan yang diperoleh sesuai dengan pengatahuan dan pengalaman sesorang tentang sesuatu.

Menurtu Zaithaml dan Bitner (dalam Kartawan dkk, 2003:105) mendifinisikan citra sebagai kesan terhadap suatu produk atau merek dari suatu perusahaan yang disimpan dalam ingatan seseorang atau kelompok yang dihasilkan melalui pengalaman di masa yang lampau. Dengan demikian apabila pengalaman dari layanan yang diterima oleh konsumen itu baik, akan membentuk citra yang baik dari perusahaan tersebut. Sebaliknya apabila layanan yang diterima itu jelek, maka akan membentuk citra yang jelek pula.

Menurut Khasali (2003:30) citra perusahaan yang baik dimaksudkan agar perusahaan dapat tetap hidup dan orang-orang di dalamnya terus

\footnotetext{
${ }^{1}$ Mahasiswa Pasca Sarjana UNRAM Program Magister Manajemen

2 Dosen Pasca Sarjana UNRAM Program Magister Manajemen
} 
mengembangkan kreativitas bahkan memberikan manfaat yang lebih berarti bagi orang lain.

\subsection{Pengaruh Citra Perusahaan Terhadap Keputusan Nasabah Dalam Memilih Jasa.}

Image atau citra yang diyakini oleh konsumen (nasabah) terhadap perusahaan jasa (Bank) sangat bervariasi dari persepsi masing-masing individu. Apabila image atau citra yang tertanam dalam suatu benak pikiran nasabah terhadap perusahaan itu baik, maka nasabah akan tetap memakai jasa pada perusahaan itu, sebaliknya bila image atau citra perusahaan yang tertanam dalam benak nasabah negatif maka harapan dalam menggunakan jasa berikutnya oleh nasabah akan menunjukkan sikap merasa tidak puas karena tidak sesuai dengan informasi yang diketahui dan tidak sesuai dengan harapannya. Image yang positif tentu menjadi kekuatan bagi perusahan yaitu jasa yang diberikan terkesan baik pada nasabah.

Citra perusahaan merupakan seperangkat keyakinan, ide, dan kesan yang dimiliki seseorang terhadap suatu objek, atau citra dapat didefinisikan sebagai suatu kesan yang timbul karena pemahaman akan suatu kenyataan (Khasali, 2003). Artinya, citra perusahaan perbankan terbentuk karena pengalaman nasabah dalam menggunakan jasa pada bank tersebut.

Melihat pentingnya keputusan nasabah dalam memilih jasa pada perusahaan, maka perusahaan harus membangun citra yang baik terhadap nasabahnya, dimana tentunya yang mengubah persepsi masyarakat akan suatu citra perusahaan. Jadi, berhasil atau tidaknya suatu perusahaan jasa, tergantung pada persepsi kosumen akan perusahaan tersebut.

Perilaku konsumen adalah kegiatan - kegiatan individu yang secara langsung terlibat dalam mendapatkan dan mempergunakan barang - barang dan jasa, termasuk didalamnya proses pengambilan keputusan pada persiapan dan penentuan kegiatan kegiatan tersebut (Swasta dan Handoko, 1982:9).

Perilaku konsumen adalah aktivitas mental dan fisik yang dilakukan oleh pelanggan rumah tangga (konsumen akhir) dan pelanggan bisnis yang menghasilkan keputusan untuk membayar, membeli, dan menggunakan produk dan jasa tertentu (Sheth, et.al. 2004).

\section{KERANGKA KONSEPTUAL}

Dari telaah pustaka di atas, maka disusun suatu kerangka konseptual penelitian yang menyatakan pengaruh antara variabel dalam penelitian ini,

\footnotetext{
${ }^{1}$ Mahasiswa Pasca Sarjana UNRAM Program Magister Manajemen

2 Dosen Pasca Sarjana UNRAM Program Magister Manajemen
} 
Gambar 2. Kerangka Konseptual Penelitian

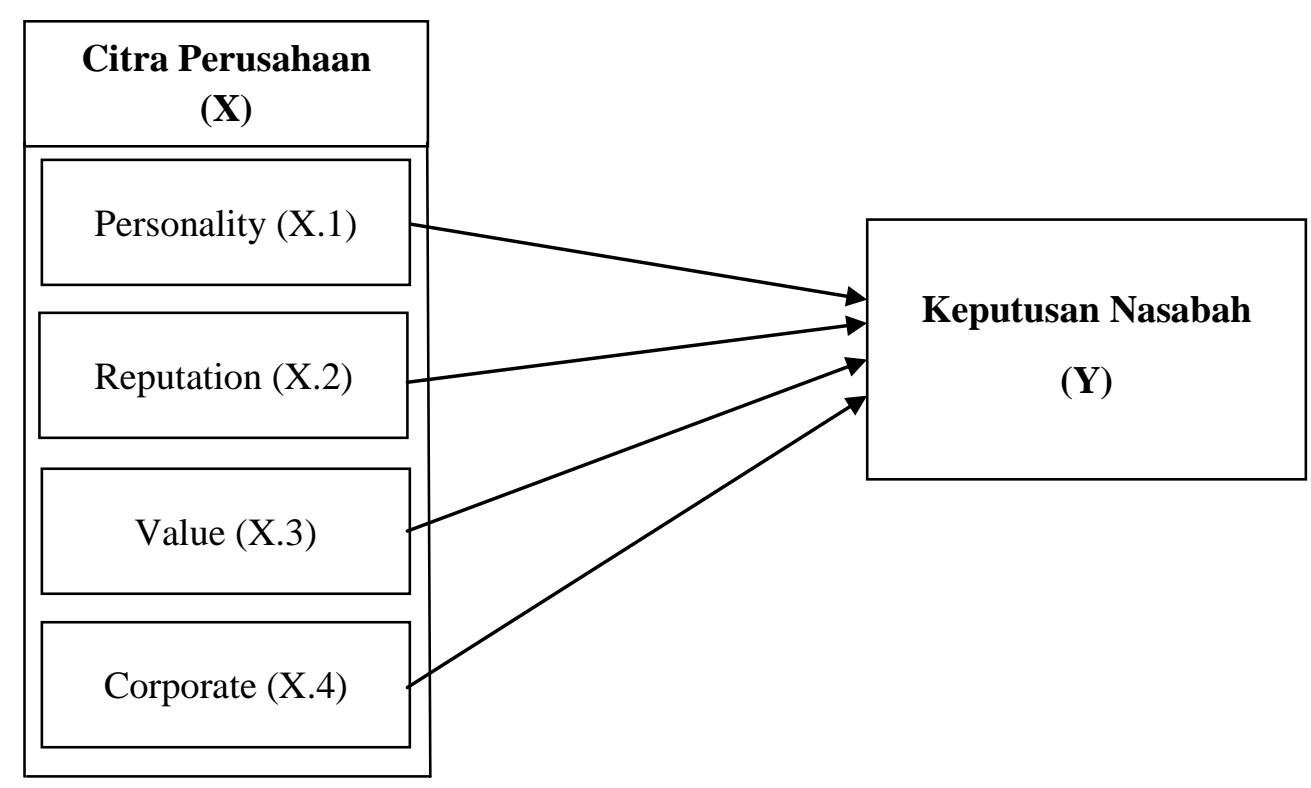

\section{METODE PENELITIAN}

Jenis penelitian lebih banyak mengacu pada rumusan masalah yang diangkat dan tujuan daripada penelitian. Jenis penelitian yang digunakan dalam penelitian ini adalah penelitian Asosiatif kausal (Sebab Akibat). Menurut Sugiyono (2011:36), rumusan masalah asosiatif adalah suatu rumusan masalah penelitian yang bersifat menanyakan hubungan antara dua variabel atau lebih. Terdapat tiga bentuk hubungan yitu: hubungan simetris, hubungan kausal (sebab akibat) dan interaktif/ resiprocal/timbal balik. Hubungan kausal adalah hubungan yang bersifat sebab akibat. Jadi disini ada variabel indipenden dan dependen.

Metode penelitian ini akan digunakan untuk mengetahui pengaruh Citra Perusahan terhadap Keputusan Nasabah dalam memilih jasa Perbankan pada PT. Bank BRI Cabang Mataram.

\subsection{Populasi dan Responden Penelitian}

Populasi adalah wilayah generalisasi yang terdiri atas obyek atau subyek yang mempunyai kualitas dan karakteristik tertentu yang ditetapkan oleh peneliti untuk dipelajari dan kemudian ditarik kesimpulannya (Sugiyono, 2003:72). Populasi dalam penelitian ini adalah seluruh nasabah PT Bank BRI Cabang Mataram Tahun 2014 yang berjumlah 150.000 orang.

Sampel adalah bagian dari jumlah dan karakteristik yang dimiliki oleh populasi tersebut (Sugiyono 2008:72)". Jika populasinya besar dan jumlah populasi tidak diketahui maka digunakan rumus Slovin yang dikutip oleh Notoatmodjo (2010) sebagai berikut:

\footnotetext{
1 Mahasiswa Pasca Sarjana UNRAM Program Magister Manajemen

2 Dosen Pasca Sarjana UNRAM Program Magister Manajemen
} 


$$
\begin{aligned}
& n=\frac{N}{1+N\left(d^{2}\right)} \\
& \text { Keterangan : } \\
& \mathrm{N}=\text { Populasi } \\
& \mathrm{n} \quad=\text { Sampel } \\
& \mathrm{d}^{2}=\text { Derajat Kepercayaan } 10 \% \text { atau } 0,1 \\
& n=\frac{150.000}{1+150.000\left(0,1^{2}\right)} \\
& n=\frac{150.000}{1+150.000(0,01)} \\
& n=\frac{150.000}{1501}=99.9 \quad \text { Dibulatkan menjadi } 100 \text { orang. }
\end{aligned}
$$

\subsection{Analisis Regresi Linear Berganda}

Data yang diperoleh melalui kuesioner akan dilakukan analisis dengan menggunakan analisis regresi linier berganda. Sugiyono (2008:277) mengemukakan analisis regresi linier berganda digunakan untuk melakukan prediksi, bagaimana perubahan nilai variabel dependen bila nilai variabel independen dinaikan atau diturunkan nilainya. Analisis ini digunakan dengan melibatkan dua atau lebih variabel bebas antara variabel dependen $(Y)$ dan variabel independen $\left(X_{1}, X_{2}\right.$, dan $\left.X_{3}\right)$, cara ini digunakan untuk mengetahui kuatnya hubungan antara beberapa variabel bebas secara serentak terhadap variabel terkait dan dinyatakan dengan rumus. berikut:

Sugiyono (2013:188) merumuskan analisis regresi linier berganda sebagai

$$
Y=a+b_{1} X_{1}+b_{2} X_{2}+b_{3} X_{3}+b_{4} X_{4}
$$

Keterangan :

$$
\begin{array}{cl}
\mathrm{Y} & =\text { Keputusan Nasabah } \\
\mathrm{a} & =\text { Konstanta } \\
\mathrm{b}_{1} \mathrm{X}_{1} & =\text { Personality } \\
\mathrm{b}_{2} \mathrm{X}_{2} & =\text { Reputation } \\
\mathrm{b}_{3} \mathrm{X}_{3} & =\text { Value } \\
\mathrm{b}_{4} \mathrm{X}_{4} & =\text { Corporate }
\end{array}
$$

\section{HASIL PENELITIAN}

\subsection{Karakteristik Responden Berdasarkan Jenis Kelamin}

Karakteristik nasabah Bank BRI Cabang Mataram berdasarkan jenis kelamin dapat dilihat pada Tabel 1 :

\footnotetext{
${ }^{1}$ Mahasiswa Pasca Sarjana UNRAM Program Magister Manajemen

2 Dosen Pasca Sarjana UNRAM Program Magister Manajemen
} 
Tabel 1 Keadaan Responden Berdasarkan Jenis Kelamin.

\begin{tabular}{|c|c|c|c|}
\hline No & Jenis Kelamin & Jumlah Responden (Nasabah) & Persentase (\%) \\
\hline 1 & Laki-laki & 61 & 61 \\
\hline 2 & Perempuan & 39 & 39 \\
\hline & Jumlah & $\mathbf{1 0 0}$ & $\mathbf{1 0 0}$ \\
\hline
\end{tabular}

Sumber : Lampiran 2

Berdasarkan Tabel 4.1 dapat dilihat bahwa mayoritas responden berjenis kelamin laki-laki dengan jumlah 61 responden atau sekitar $61 \%$. Sedangkan responden yang berjenis kelamin perempuan berjumlah 39 responden atau sekitar $39 \%$ dari jumlah keseluruhan responden.

6.2. Keadaan Responden Berdasarkan Umur Responden

Tabel 2 Keadaan Responden Berdasarkan Umur Responden.

\begin{tabular}{|c|c|c|c|}
\hline No & Umur (tahun) & Jumlah (Nasabah) & Prosentase $\%$ \\
\hline 1 & $<21$ & 20 & 20 \\
\hline & $21-30$ & 39 & 39 \\
\hline 2 & $31-40$ & 23 & 23 \\
\hline 3 & $>41$ & 18 & 18 \\
\hline \multicolumn{2}{|c|}{ JUMLAH } & $\mathbf{1 0 0}$ & $\mathbf{1 0 0}$ \\
\hline
\end{tabular}

Sumber : Lampiran 2

Berdasarkan Tabel 4.2 dapat dilihat bahwa tingkatan usia responden terbesar adalah yang berusia antara 21-30 tahun dengan jumlah 39 responden atau sekitar $39 \%$ dari jumlah keseluruhan responden. Sedangkan tingkatan usia responden terkecil adalah yang berusia diatas 41 tahun dengan jumlah 18 responden atau sekitar 18\% dari jumlah keseluruhan responden.

6.3. Keadaan Responden Berdasarkan Pekerjaan Responden.

Tabel 3 Keadaan Responden Berdasarkan Pekerjaan Responden.

\begin{tabular}{|c|c|c|c|}
\hline No & Pekerjaan & Jumlah (Nasabah) & Prosentase (\%) \\
\hline 1 & Pelajar & 6 & 6 \\
\hline 2 & Mahasiswa & 14 & 14 \\
\hline 3 & PNS & 20 & 20 \\
\hline 4 & Pegawai Swasta & 34 & 34 \\
\hline 5 & Wiraswasta & 26 & 26 \\
\hline \multicolumn{2}{|c|}{ JUMLAH } & 100 & 100 \\
\hline
\end{tabular}

Sumber : Lampiran 2

\footnotetext{
${ }^{1}$ Mahasiswa Pasca Sarjana UNRAM Program Magister Manajemen

2 Dosen Pasca Sarjana UNRAM Program Magister Manajemen
} 
Berdasarkan Tabel 4.3 dapat dilihat bahwa tingkat pekerjaan responden terbesar adalah pegawai swasta dengan jumlah 34 responden atau sekitar $34 \%$, sedangkan tingkat pekerjaan yang terkecil adalah pelajar berjumlah 6 responden atau sekitar $6 \%$. Selebihnya wiraswasta dengan jumlah 26 atau sekitar $26 \%$, PNS dengan jumlah 20 responden dan mahasiswa dengan jumlah 14 orang.

\subsection{Keadaan Responden Berdasarkan Lama Menjadi Nasabah.}

Karakteristik nasabah Bank BRI Cabang Mataram berdasarkan lama menjadi nasabah dapat dilihat pada Tabel 4 :

Tabel 4 Keadaan Responden Berdasarkan Lama Menjadi Nasabah.

\begin{tabular}{|c|c|c|c|}
\hline No & $\begin{array}{c}\text { Lama menjadi } \\
\text { nasabaha (Tahun) }\end{array}$ & $\begin{array}{c}\text { Jumlah } \\
\text { (Nasabah) }\end{array}$ & Prosentase (\%) \\
\hline 1 & $<2$ & 5 & 5 \\
\hline 2 & $2-5$ & 20 & 20 \\
\hline 3 & $6-10$ & 50 & 50 \\
\hline 4 & $>10$ & 25 & 25 \\
\hline \multicolumn{2}{|r|}{ JUMLAH } & 100 & 100 \\
\hline
\end{tabular}

Sumber : Lampiran 2

Dari tabel 4.4 tersebut menunjukan bahwa responden sebagian besar lama menjadi nasabah Bank BRI Cabang Mataram adalah 6-10 tahun dengan jumlah 50 orang nasabah, sedangkan sebagian kecil yang lama menjadi nasabah adalah kurang dari 2 tahun dengan jumlah 5 orang nasabah.

\subsection{Analisis Regresi Linear Berganda}

Tabel 5. Hasil Uji Regresi Linier Berganda Variabel X (Personality, Reputation, Value, dan Corporate)

\begin{tabular}{|l|c|c|c|c|c|c|}
\hline \multicolumn{1}{|c|}{ Model } & \multicolumn{2}{|c|}{$\begin{array}{c}\text { Unstandardized } \\
\text { Coefecients }\end{array}$} & $\begin{array}{c}\text { Standardized } \\
\text { Coefecients } \\
\text { Beta }\end{array}$ & $\mathbf{t}$ & Sig & $\begin{array}{c}\text { Ket. } \\
\mathbf{a}(\mathbf{0 . 0 5})\end{array}$ \\
\cline { 2 - 8 } & $\mathbf{B}$ & Std. Error & & & & \\
\hline (Constant) & .663 & .359 & & & & \\
\hline $\begin{array}{l}\text { Personality } \\
\left(\mathrm{X}_{1}\right)\end{array}$ & .383 & .071 & .442 & 5.417 & .000 & Signifikan \\
\hline $\begin{array}{l}\text { Reputation } \\
\left(\mathrm{X}_{2}\right)\end{array}$ & .145 & .053 & .208 & 2.754 & .007 & Signifikan \\
\hline Value $\quad\left(\mathrm{X}_{3}\right)$ & .124 & .043 & .217 & 2.872 & .005 & Signifikan \\
\hline $\begin{array}{l}\text { Corporate } \\
\left(\mathrm{X}_{4}\right)\end{array}$ & .175 & .067 & .207 & 2.627 & .010 & Signifikan \\
\hline
\end{tabular}

a. Dependent Variabel: Keputusan Nasabah

Sumber : Lampiran 6

\footnotetext{
${ }_{1}$ Mahasiswa Pasca Sarjana UNRAM Program Magister Manajemen

2 Dosen Pasca Sarjana UNRAM Program Magister Manajemen
} 
Dari tabel 5. tujuannya adalah untuk meramalkan atau memprediksi besaran nilai variabel dependen yang dipengaruhi oleh variabel independen atau menunjukan bahwa model persamaan regresi berganda yaitu untuk memperkirakan keputusan nasabah yang dipengaruhi oleh elemen citra perusahaan adalah :

$$
\mathrm{Y}=0.663+0.383\left(\mathrm{X}_{1}\right)+0.145\left(\mathrm{X}_{2}\right)+0.124\left(\mathrm{X}_{3}\right)+0.175\left(\mathrm{X}_{4}\right)
$$

$\mathrm{Y}$ adalah keputusan nasabah, $\mathrm{X}_{1}$ adalah personality, $\mathrm{X}_{2}$ adalah reputation, $\mathrm{X}_{3}$ adalah value, dan $\mathrm{X}_{4}$ adalah corporate. Dari persamaan diatas, dapat dianalisis beberapa hal, antara lain:

a). Nilai kostanta sebesar 0.663 bermakna bahwa apabila variabel bebas yang terdiri dari Personality (X1), Reputation (X2), Value (X3) dan Corporate (X4) di asumsikan tetap atau tidak mengalami perubahan baik peningkatan ataupun penurunan maka nilai dari keputusan nasabah adalah sebesar 0.663 yang berarti tidak ada keputusan. Interpretasi ini merujuk pada skala interval yang digunakan dalam skala likert, dimana keputusan nasabah sangat rendah berada pada rentang 1-1,79, sedangkan konstanta bernilai 0.663 yang berarti tidak ada keputusan.

b). Koefisien regresi untuk variabel personality (X1) sebesar 0.383 ; bermakna bahwa jika terjadi peningkatan pada variabel personality sebesar $100 \%$ maka akan terjadi peningkatan juga pada variabel keputusan nasabah sebesar 38,30\% dengan asumsi variabel Reputation (X2), Value (X3) dan Corporate (X4) tetap atau tidak mengalami perubahan.

c). Koefisien regresi untuk variabel Reputation (X2) sebesar 0.145; bermakna bahwa jika terjadi peningkatan pada variabel reputation sebesar $100 \%$ maka akan terjadi peningkatan juga pada variabel keputusan nasabah sebesar $14,50 \%$ dengan asumsi variabel personality (X1), Value (X3) dan Corporate (X4) tetap atau tidak mengalami perubahan.

d). Koefisien regresi untuk variabel Value (X3) sebesar 0.124; bermakna bahwa jika terjadi peningkatan pada variabel value sebesar $100 \%$ maka akan terjadi peningkatan juga pada variabel keputusan nasabah sebesar $12,40 \%$ dengan asumsi variabel personality (X1), Reputation (X2) dan Corporate (X4) tetap atau tidak mengalami perubahan.

e). Koefisien regresi untuk variabel Corporate (X4) sebesar 0.175; bermakna bahwa jika terjadi peningkatan pada variabel corporate sebesar 100\% maka akan terjadi peningkatan juga pada variabel keputusan nasabah sebesar $17,50 \%$ dengan asumsi variabel personality $(X 1)$, Reputation $(X 2)$ dan Value $(X 3)$ tetap atau tidak mengalami perubahan.

\subsection{Pengujian Hipotesis (Uji F/Simultan)}

Untuk menguji pengaruh variabel bebas secara bersama-sama, maka dilakukan dengan uji F. Hasil perhitungan regresi linier berganda secara simultan diperoleh sebagai berikut :

\footnotetext{
${ }^{1}$ Mahasiswa Pasca Sarjana UNRAM Program Magister Manajemen

2 Dosen Pasca Sarjana UNRAM Program Magister Manajemen
} 
Tabel 6. Hasil Uji Regresi Linear Berganda Secara Simultan

\begin{tabular}{|c|c|c|c|}
\hline Model & F & Sig. & Keterangan \\
\hline Regression & 23.265 & $.000^{\mathrm{a}}$ & $\begin{array}{c}\text { Ada pengaruh secara } \\
\text { simultan }\end{array}$ \\
\hline
\end{tabular}

a. Predictors: (Constant), X3, X1, X2, X4. b. Dependent Variable: Y Sumber : Lampiran 6

Hasil perhitungan statistik menunjukkan nilai $\mathrm{F}_{\text {hitung }}$ sebesar 23.265 dengan signifikansi 0.000 . Apabila dibandingkan dengan $\mathrm{F}_{\text {tabel }}$ sebesar 2.47 artinya hipotesis observasi (Ho) ditolak dan menerima hipotesis alternatif $(\mathrm{Ha})$.

Menurut Siregar (2013:439), $\mathrm{F}_{\text {tabel }}$ dapat diketahui dengan perhitungan

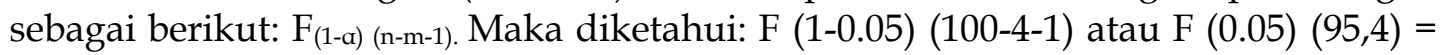
$\mathrm{F}_{\text {tabel }} 2.47$ (sumber: lampiran 8, hal. 4). Dengan demikian dapat disimpulkan bahwa personality, reputation, value, corporate berpengaruh positif dan signifikan secara simultan terhadap keputusan nasabah. Hal ini menunjukan secara keseluruhan tentang karakteristik Bank BRI dalam kaitannya dengan produk unggulan dan tanggung jawab sosial. Serta adanya pengalaman yang pernah dialami oleh nasabah pada Bank BRI tentang nilai-nilai atau budaya yang dimiliki Bank BRI seperti kemampuan karyawan atau staf BRI dan kemudahan dalam mengenal Bank BRI dari pengenalan Logo, Warna dan Slogan Bank BRI. Hal mampu mempengaruhi keputusan nasabah dalam menggunakan kembali jasa Bank BRI Cabang Mataram.

\subsection{Pengujian Hipotesis Variabel Dominan}

Terdapat pengaruh dominan dari keempat variabel bebas yaitu reputation, value, corporate dan personality. Dari tabel 4.16 nampak nilai yang tertinggi dari keempat variabel bebas terlihat pada variabel personality sebesar 0.442 artinya variabel yang paling berpengaruh kuat terhadap keputusan nasabah adalah personality. Hal ini terlihat hasil penelitian bahwa dengan adanya personality perusahaan yang baik maka mampu meningkatkan keinginan nasabah secara kuat dalam mengambil keputusan untuk menggunakan jasa perbankan pada Bank BRI Cabang Mataram.

\section{PEMBAHASAN}

a) Pengaruh Personality terhadap Keputusan Nasabah

Pada penelitian ini, variabel personality terbukti berpengaruh signifikan terhadap keputusan nasabah dengan nilai thitung sebesar 5.417 dan tingkat signifikansi 0.000 dengan keterangan signifikan. Hasil ini terbukti menerima hipotesis alternatif (Ha). Kesimpulannya secara parsial personality berpengaruh signifikan terhadap keputusan nasabah. Hasil penelitian ini didukung penelitian sebelumnya yang dilakukan oleh Yusrina, (2013), Yuliawan, (2011), Ulinuha, A., (2010), Rosim (2013), Pratama, (2013), Farida., (2010), terbukti bahwa personality berpengaruh signifikan terhadap keputusan nasabah.

Dari beberapa penelitian tersebut sesuai dengan menurut Harrison (1995) menyatakan bahwa personality merupakan elemen citra perusahan yang dapat mempengaruhi keputusan nasabah. Dimana keseluruhan karakteristik perusahaan

\footnotetext{
${ }^{1}$ Mahasiswa Pasca Sarjana UNRAM Program Magister Manajemen

2 Dosen Pasca Sarjana UNRAM Program Magister Manajemen
} 
yang dipahami publik sasaran seperti perusahaan yang dapat dipercaya, perusahaan yang mempunyai tanggung jawab sosial.

\section{Pengaruh Reputation terhadap Keputusan Nasabah}

Pada penelitian ini, variabel reputation terbukti berpengaruh signifikan terhadap keputusan nasabah dengan nilai $t_{\text {hitung }}$ sebesar 2.754 dan tingkat signifikansi 0.007 dengan keterangan signifikan. Hasil ini terbukti menerima hipotesis alternatif (Ha). Kesimpulannya secara parsial reputation berpengaruh signifikan terhadap keputusan nasabah. Hasil penelitian ini didukung penelitian sebelumnya yang dilakukan oleh Ulinuha, A., (2010), Rosim (2013), Pratama, (2013), Farida., (2010), terbukti bahwa reputation berpengaruh signifikan terhadap keputusan nasabah.

Menurut Davies et al (dalam Nha Nguyen, 2001:63) citra perusahaan merupakan keseluruhan kesan yang terbentuk di benak masyarakat tentang perusahaan. Di mana citra tersebut berhubungan dengan nama bisnis, arsitektur, variasi dari produk, tradisi, ideologi dan kesan pada kualitas komunikasi yang dilakukan oleh setiap karyawan yang berinteraksi dengan klien organisasi.

\section{Pengaruh Value terhadap Keputusan Nasabah}

Pada penelitian ini, variabel value terbukti berpengaruh signifikan terhadap keputusan nasabah dengan nilai $t_{\text {hitung }}$ sebesar 2.872 dan tingkat signifikansi 0.005 dengan keterangan signifikan. Hasil ini terbukti menerima hipotesis alternatif (Ha). Kesimpulannya secara parsial value berpengaruh signifikan terhadap keputusan nasabah. Hasil penelitian ini didukung penelitian sebelumnya yang dilakukan oleh Rosim (2013), Daulay (2006), Pratama, (2013), Farida., (2010), terbukti bahwa value berpengaruh signifikan terhadap keputusan nasabah.

Dari hasil penelitian dan beberapa penelitian terdahulu, hal ini juga dapat dibuktikan dari tanggapan responden (nasabah) bahwa value Bank BRI Cabang Mataram mampu mempengaruhi keputusan nasabah dalam menggunakan jasa perbankan. Dimana penilaian responden tentang nilai-nilai atau budaya yang dimiliki Bank BRI seperti kemampuan karyawan atau staf BRI di kategorikan baik. Hal ini dapat dilihat pada hasil berikut ini :

\section{Pengaruh Corporate terhadap Keputusan Nasabah}

Pada penelitian ini, variabel corporate terbukti berpengaruh signifikan terhadap keputusan nasabah dengan nilai $t_{\text {hitung }}$ sebesar 2.627 dan tingkat signifikansi 0.005 dengan keterangan signifikan. Hasil ini terbukti menerima hipotesis alternatif (Ha). Kesimpulannya secara parsial corporate berpengaruh signifikan terhadap keputusan nasabah. Hasil penelitian ini didukung penelitian sebelumnya yang dilakukan oleh Yusrina, (2013), Rosim (2013), Daulay (2006), Pratama, (2013), Farida., (2010), terbukti bahwa corporate berpengaruh signifikan terhadap keputusan nasabah.

Menurut Nguyen, Nha dan Gaston Leblanc (2005), Corporate Identity (Identitas Perusahaan) adalah apa yang senyatanya ada pada atau ditampilkan oleh perusahaan. Identitas merupakan pernyataan singkat perusahaan kepada

\footnotetext{
${ }^{1}$ Mahasiswa Pasca Sarjana UNRAM Program Magister Manajemen

2 Dosen Pasca Sarjana UNRAM Program Magister Manajemen
} 
masyarakat tentang apa dan siapa mereka itu. Identitas perusahaan dapat membedakan perusahaan yang satu dengan yang lain. Identitas perusahaan terdiri dari dua elemen pokok, yaitu nama dan logo (Sutojo,2004;14).

\section{Pengaruh Personality, Reputation, Value dan Corporate terhadap Keputusan} Nasabah

Hasil perhitungan statistik (SPSS) menunjukkan bahwa Personality, Reputation, Value dan Corporate berpengaruh positif dan signifikan secara simultan terhadap keputusan nasabah Bank BRI Cabang Mataram dalam menggunakan jasa perbankan. Hal ini menunjukan bahwa personality Bank BRI dalam tanggung jawab sosial di nilai oleh masyarakat (nasabah) di kategorikan Baik. Hal ini BRI selalu menunjukan partisipasi atau perhatian terhadap lingkungan sekitar. Serta BRI selalu melibatkan beberapa karyawan dan staf untuk berpartisipasi membantu dalam rangka penghijauan lingkungan sekitar dengan tujuan menjaga dan melestarikan kekayaan alam. Dalam hal ini BRI selalu mengutamakan kepentingan nasabah dengan memberikan bantuan terhadap nasabah yang ingin mengembangkan usaha mandiri maupun kelompok. Adanya reputation perusahaan yang dialami oleh nasabah pada pengalaman yang pernah nasabah alami yaitu pada Bank BRI Cabang Mataram dengan adanya kinerja keamanan transaksi sebuah bank dan pelayanan yang memuaskan.

\section{KESIMPULAN}

a). Terdapat pengaruh yang signifikan dari personality sebagai elemen citra perusahaan terhadap Keputusan Nasabah dalam memilih Jasa Perbankan PT. BRI Cabang Mataram.

b). Terdapat pengaruh yang signifikan dari reputation sebagai elemen citra perusahaan terhadap Keputusan Nasabah dalam memilih Jasa Perbankan PT. BRI Cabang Mataram.

c). Terdapat pengaruh yang signifikan dari value sebagai elemen citra perusahaan terhadap Keputusan Nasabah dalam memilih Jasa Perbankan PT. BRI Cabang Mataram.

d). Terdapat pengaruh yang signifikan dari corporate sebagai elemen citra perusahaan terhadap Keputusan Nasabah dalam memilih Jasa Perbankan PT. BRI Cabang Mataram.

e). Hasil penelitian membuktikan bahwa variabel personality memiliki pengaruh paling dominan terhadap Keputusan Nasabah dalam memilih Jasa Perbankan PT. BRI Cabang Mataram.

\section{REKOMENDASI}

Saran yang dapat dijadikan masukan kepada pihak PT. Bank Rakyat Indonesia (Persero) Tbk. Kantor Cabang Mataram, yaitu :

a) Sesuai dengan hasil penelitian bahwa elemen citra perusahaan (Bank BRI Cabang Mataram) yaitu terdiri dari personality, reputation, value, dan corporate, menunjukan mampu mempengaruhi keputusan nasabah dalam menggunakan jasa perbankan pada Bank BRI Cabang Mataram.

\footnotetext{
${ }^{1}$ Mahasiswa Pasca Sarjana UNRAM Program Magister Manajemen

2 Dosen Pasca Sarjana UNRAM Program Magister Manajemen
} 
Dari hasil penelitian ini, BRI Cabang Mataram dapat mempertahankan dalam hal karakteristik Bank dalam kaitannya dengan produk unggulan dan tanggung jawab sosial. Menjaga kepercayaan nasabah terhadap pengalaman yang pernah nasabah alami atau orang lain alami pada Bank BRI Cabang Mataram. Serta nilai-nilai atau budaya yang dimiliki Bank BRI seperti sikap dan kemampuan karyawan atau staf BRI dan memberikan gambaran bermakna terhadap identitas perusahaan yaitu kemudahan dalam mengenal Bank BRI dari pengenalan Logo, Warna dan Slogan Bank BRI. Hal ini semua dapat dipertahankan agar nasabah dalam memutuskan sebuah keinginan dalam menggunakan jasa perbankan khususnya pada jasa layanan Bank BRI Cabang Mataram.

Pada pihak manajemen PT. Bank BRI Cabang Mataram dapat mempertahankan lagi bahkan meningkatkan citra perusahaan tersebut di mata nasabahnya. Peningkatan citra dapat dilakukan dengan cara sebagai berikut :

1) Lebih meningkatkan pengaruh pengetahuan konsumen dengan memberikan informasi lagi yang berhubungan dengan keunggulan produknya yang berupa tabungan itu sendiri, hal ini perlu dilakukan agar masyarakat terdorong untuk menjadi nasabah.

2) Efektivitas kegiatan promosi lebih ditingkatkan lagi melalui dengan cara meningkatkan dengan melakukan program promosi yang lebih efektif seperti promosi pada media elektronik, disosialisasikannya perbedaan antara tingkat suku bunga dengan pembagian hasil, meningkatkan kualitas pelayanan sumber daya yang tersedia, meningkatkan kenyamanan dan ketersediaan sarana dan prasarana.

b) Untuk peneliti selanjutnya, jika melakukan penelitian yang serupa, diharapkan dapat menambah variabel-variabel lain yang dapat mempengaruhi keputusan nasabah, misalanya Kepercayaan dan CRM (Customer Relationship Manajemen). CRM adalah suatu pendekatan yang menyeluruh untuk menciptakan, memelihara, dan mengembangkan hubungan dengan nasabah. Penelitian ini juga dapat dijadikan rujukan bagi peneliti sejenis berikutnya.

\section{DAFTAR PUSTAKA}

Farida, N., (2010), Pengaruh Ikatan Hubungan, Citra Perusahaan, Nilai Pelanggan, Kualitas dan Kepuasan Nasabah Terhadap Loyalitas Nasabah Bank Pemerintah Di Jawa Tengah. Jurnal Manajmen Sosial dan Politk UNDIP, 13 (12) : pp202-213. Tersedia di http://wacana.ub.ac.id/index.php/wacana/article/view/165/142.pdf. diakses tanggal 12 Juli 2015.

Ibnu Syamsi. (1995). Pengambilan Keputusan dan Sistem Informasi. Jakarta: Bumi Aksara.

Khasali, R., 2003, Membidik Pasar Indonesia: Segmenting, Targeting, Positioning, PT. Gramedia Pustaka Utama, Jakarta.

Kotler, Philip dan Kevin Lane Keller. 2008. Manajemen Pemasaran. Jilid 2. Edisi 12. Alih Bahasa Benyamin Molan. Jakarta: indeks.

\footnotetext{
${ }^{1}$ Mahasiswa Pasca Sarjana UNRAM Program Magister Manajemen

2 Dosen Pasca Sarjana UNRAM Program Magister Manajemen
} 
Kotler, Phillip dan Gary Amstrong. (2008). Prinsip-Prinsip Pemasaran. Erlangga, Jakarta.

Nguyen, Nha dan Leblanc, Gaston. 2001.Corporate Image and CorporateReputation in Customers'

RetentionDecisions in Services. Journal of Retailing and Consumer Services,(Online), ol.

8, pp. 227-236. Tersedia di (http// www.proquest.com, diakses 25Juni 2010).

Notoatmodjo, S. 2010. Metodologi Penelitian Kesehatan. Jakarta : Rineka Cipta

Rosim., 2013, Pengaruh Kualitas Produk, Citra Perusahaan, Promosi dan Desain Terhadap

Keputusan Pembelian Sepeda Motor Yamaha. Jurnal Manajemen Fakultas Ekonomi dan Bisnis Universitas Islam Negeri Syarif Hidayatullah Jakarta. Diakses tanggal 27 Maret 2015. Tersedia di http:// repository. uinjkt.ac.id/ dspace/ bitstream/ 123456789/23946/1/Rosim\%20\%28206081004236\%29.pdf

Salusu, I. 2003. Pengambilan Keputusan Stratejik untuk Organisasi Publik dan Organisasi Nonprofit. Penerbit: Grasindo, Jakarta.

Swasta B.DH dan Handoko, T.H., 1982. Manajemen Pemasaran Analisa Perilaku Konsumen. Yogyakarta. Liberty.

Schiffman, Leon dan Leslie Lazar kanuk, (2008), Perilaku Konsumen. Edisi Keempat. Jakarta : Indeks

Sutisna. (2001). Perilaku Konsumen dan Komunikasi Pemasaran. PT. Remaja Rosdakarya, Bandung.

Sheth, Jgdish, Banwari Mittal, (2004), Consumer Behavior: A Managerial Perspective 2e, USA: Thomson South Western.

Sugiyono., 2008, Metode Penelitian Bisnis. Cetakan Kesebelas. Bandung : CV. Alfabeta. .2011, Metode Penelitian Kuantitatif kualitatif dan RED. Bandung: Alfabeta.

Sinungan, M., 2000, Manajemen Dana Bank, Jakarta : Bumi Aksara.

Ulfa, S.N., (2006), "Hubungan Antara Citra Merek Dengan Loyalitas Nasabah PT. Bank Rakyat Indonesia (Persero) Tbk. Kantor Cabang Purbalingga, Skripsi Program Studi Psikologi Fakultas Kedokteran Universitas Diponegoro Semarang. diakses tanggal 17 september 2015. Tersedia di http:/ / eprints.undip.ac.id/13572/1/SECHESTIN.pdf

Yusrina, 2013, "Peranan Citra Perusahaan Terhadap Kepercayaan Nasabah Bank BRI Cabang Bandah Aceh", Jurnal Manajemen dan bisnis, 1 (2) : pp204. Diakses tanggal 17 september 2015. Tersedia di https://lppmekubank. files.wordpress.com/2013/06/citra-perusahaan-dan-kepercayaan-nasabahyusrina.pdf

Zeithaml, Valarie A., Mary Jo Bitner, dan Dwayne D. Gremler. 2006. Service Marketing Integrating Customer Focus Accross The Firm 4th Edition. New York:McGraw Hill. 